\title{
KE STAVU PÉČE O NĚMECKÉ KULTURNÍ DĚDICTVÍ V ČESKÉM POHRANIČí NA PŘÍKLADU CHOMUTOVSKA
}

\author{
STANISLAV DĚD
}

\begin{abstract}
On the State of Protection of German Cultural Heritage in the Czech Borderlands: The View from Chomutov

This discussion highlights the unsatisfactory state of care for local German cemeteries in the Czech borderlands, a topic that deserves attention not only in the context of the Czech-German relations, but also in the context of the celebration of 2018 as the European Year of Cultural Heritage. The author served as a director of the Regional Museum in Chomutov (Komotau), a town in north-western Bohemia. Against this background, he reflects on the causes of this dire state, pointing to the insufficient performance of the relevant Czech authorities in the protection of cultural heritage. Furthermore, he presents positive examples of civic engagement towards Czech-German reconciliation. Keywords: Czech Republic; cultural heritage; cemeteries; Sudeten Germans; Czech-German relations; reconciliation
\end{abstract}

DOI: $10.14712 / 23363231.2019 .3$

\section{Úvod}

Péče o kulturní dědictví je těsně spjata s tzv. kulturou vzpomínání, jež se po více než dvě desetiletí těší v západoevropských zemích zvýšené pozornosti jak odborníků, tak i laických zájemců o minulost. Kultura vzpomínání se postupně

Stanislav Děd je emeritní ředitel Oblastního muzea v Chomutově.

Korespondenční adresa: Voskovcova 1075/49, 15200 Praha 5. E-mail: stanislav.ded@gmail.com. Tento diskusní příspěvek je písemnou verzí referátu, jejž autor přednesl v rámci workshopu „Grenze, Gedächtnis, Friedhöfe / Hranice, pamět', hřbitovy“ pořádaného výzkumným konsorciem Grenze/n in Erinnerungskulturen ve dnech 26. a 27. záŕí 2018 v Praze. 
stává předmětem zájmu i v České republice. Cílem tohoto textu není rozebírat kulturu vzpomínání z teoretického hlediska. Je ale namístě poukázat na její historickou podmíněnost i tematickou a teritoriální různorodost a položit si otázku, kdo je k práci na poli poznání a uchovávání kulturního dědictví z povahy věci disponován a kdo má možnost kontaktů s jejími aktéry. Dále je třeba se ptát, zda má kultura vzpomínání své pevné místo v kulturní politice České republiky, a to jak po stránce normativní, tak z hlediska praktické realizace. Ta budiž sledována na prŕíkladu sedmnáctileté činnosti Oblastního muzea v Chomutově, tj. v kraji typicky pohraničním a do roku 1945 jazykově převážně německém, který se stal vpravdě laboratoří poválečného vývoje.

\section{Výchozí situace: důsledky vyhánění a nuceného vysídlení}

Téměř třicet let, které uplynuly od sametové revoluce, již umožňují pohled na situaci Chomutovska, ale i českého pohraničí jako celku, s jistým odstupem a možností zobecnění. Za hlavní téma tohoto regionu je třeba považovat hledání identity, což se týká také kultury vzpomínání. Proč tomu tak je?

Chomutov byl podle výsledků sčítání obyvatel v roce 1930 jako sudetoněmecké město s 33279 obyvatel ${ }^{1}$ představitelem specifické, třínárodní či spíše trríetnické kultury. Druhou světovou válkou však tato tradiční společnost zanikla. Po podpisu mnichovské dohody, která začlenila Chomutov do nacistické Třetí říše, odešli v říjnu 1938 z města téměř všichni čeští obyvatelé. ${ }^{2}$ Nacistické řádění v letech 1938-1945 pak nepřežila komunita židovská. Nakonec v období let 1945-1947 došlo k situaci, která zásadně poznamenala celou oblast.

Vyhnáním a nuceným vysídlením německého obyvatelstva i opatřeními, která vytvořila podmínky života té části německé menšiny, jíž bylo z utilitárních důvodů dovoleno zůstat $\mathrm{v}$ jejím původním domově, se prakticky veškerá lidová tradice a především intelektuální bohatství staly mrtvou historickou a literární záležitostí, uchovávanou pouze ve vlastivědných publikacích německých regionalistů. ${ }^{3}$ Kořeny spojující tisíci pout dětskou duši se zvyky předků, místopisem krajiny, lidovými pověstmi, písněmi a slovesným uměním z kraje vzešlých

1 Historický lexikon obcí České republiky. 1869-2011, Český statistický úřad, https://www .czso.cz/csu/czso/iii-pocet-obyvatel-a-domu-podle-kraju-okresu-obci-a-casti-obci-v-letech-1869 -2011_2015.

2 Petr Rak, Chomutov 1252-2001. Vybraná data ze 750 let historie města (Chomutov: Město Chomutov, 2002), 113.

3 Srov. Heimatkunde des Bezirkes Komotau, 26 sv. (Komotau: Deutscher Bezirkslehrerverein, 1926-1940). 
autorů, se stavbami, starými řemesly, církevními slavnostmi, poutěmi, trhy - to vše bylo naráz přetato. $Z$ hlediska duchovního obsahu byl kraj zcela vyprázdněn, vycházíme-li z toho, že podoba tradice je vždy jedinečná a vázaná na konkrétního nositele, bez něhož nemůže existovat.

V následujících desetiletích prošel kraj třemi zásadními změnami, které ve výsledku zformovaly jeho dnešní podobu. Zásadně se proměnilo národnostní složení, hospodářské využití i duchovní život regionu.

Př́ichodem desetitisíců nových obyvatel došlo především k téměř totálnímu nahrazení původního obyvatelstva dosídlenci. ${ }^{4}$ Každá skupina novousedlíků byla vybavena vlastním systémem hodnot a neměla důvod přebírat místní tradice. Navíc sama byla $z$ vlastní tradice v původním domově vytržena. Postoj ke všemu německému, tedy i k německému kulturnímu dědictví, byl všeobecně odmítavý, podezíravý a živený státní propagandou. Nadto národnostní život německé menšiny až do roku 1968 v zásadě neexistoval, což způsobilo její praktické odnárodnění.

Plastické vylíčení průběhu vyhnání najdeme v řadě dokumentárních materiálů a osobních výpovědí shromažd'ovaných bývalými německými obyvateli ve formě publikací a krajanského tisku, ${ }^{5}$ stejně jako v souborech dokumentů publikovaných odbornými institucemi jako Collegium Carolinum. ${ }^{6}$ Oba typy materiálů, byt' vznikly z odlišných důvodů, připomínají postupné obsazování pohraničního území Rudou armádou, Revolučními gardami a jednotkami Svobodovy armády, obnovování československé státní správy, existenci internačních táborů s velmi drsnými životními podmínkami, „divoký“ i organizovaný odsun, tábory nucených prací, praktické problémy každodenního života způsobené vylidněním kraje, uzavření hranic v důsledku politické situace, očekávání dosídlenců a jejich střet s realitou, postavení zůstavší německé menšiny, jakož i její vztah k obnovenému československému státu i ke komunitě vyhnaných a vysídlených spoluobčanů v Německu.

4 Počet obyvatel Chomutova nejdříve klesl v důsledku odsunu na několik stovek osob, poté se dosídlením zvýšil na 28848 osob v roce 1950. Viz Historický lexikon obcí České republiky. 18692011, Český statistický úřad, https://www.czso.cz/csu/czso/iii-pocet-obyvatel-a-domu-podle-kraju-okresu-obci-a-casti-obci-v-letech-1869-2011_2015.

5 Sudetoněmecký narativ viz Roland J. Hoffmann a Alois Harasko, eds. Odsun. Die Vertreibung der Sudetendeutschen. Dokumentation zu Ursachen, Plannung und Realisierung einer „ethnischen Säuberung" in der Mitte Europas 1848/49-1945/46, 2 sv. (München: Sudetendeutsches Archiv, 2000 a 2010); Gerald Bretfeld, Ztracená vlast. Ves v českém Krušnohoří. Orasín a jeho okolí (Chomutov: Tiskárna Akord, 2017).

6 Tomáš Staněk, Internierung und Zwangsarbeit: Das Lagersystem in den böhmischen Ländern 1945 1948 (München: Oldenbourg, 2007). Jedná se o doplněné a aktualizované vydání české verze knihy Tomáš Staněk, Tábory v Ceských zemích 1945-1948 (Šenov: Tilia, 1996). 
Významnou předností uvedených materiálů je jejich osobní charakter a spojení s konkrétními lokalitami, potažmo s prožitými událostmi. Častá námitka pracovníků odborných institucí včetně archivů, totiž že popisované události nejsou objektivně doloženy řádnými úředními protokoly, je vyvracena shodou respondentů v stále častěji dostupných a studovaných materiálech, stejně jako i narůstající řadou odborných publikací. ${ }^{7}$ Situace pramenů české provenience, zejména těch osobního charakteru a pocházejících z autentické doby, je sice nepoměrně chudší, přesto takové materiály existují. ${ }^{8} \mathrm{~K}$ dispozici jsou i souhrnné materiály s regionálním zaměřením jako závěrečné vysokoškolské práce a odborné studie. ${ }^{9}$ Materiály nakonec po bádání v archivech doplňují i požadované „úředni“" protokoly. ${ }^{10}$

V rámci tzv. „ocelové koncepce“ hospodářství doznala hlubokých zásahů také po staletí utvářená kulturní krajina Chomutovska. Důraz na budování těžkého průmyslu (povrchových dolů, elektráren a železáren) vedl k utlumení dříve převažujícího lehkého a spotřebního průmyslu a zároveň způsobil obrovské škody na životním prostředí. Současně došlo k likvidaci rozsáhlých nejúrodnějších

\footnotetext{
7 Shrnutí diskusí, jež byly na téma „odsunu“ vedeny v samizdatu a na stránkách exilových časopisů, viz Bohumil Černý, Jan Křen, Václav Kural a Milan Otáhal, eds. Češi, Němci, odsun. Diskuse nezávislých historiků (Praha: Academia 1990). V devadesátých letech odvedla velkou práci na výzkumu tohoto tématu Československo-německá, resp. Česko-německá komise historiků. Soupis děl viz „Publikace“, Česko-německá a Slovensko-německá komise historiků, http://www.dt-ds -historikerkommission.de. Z nejnovějších publikací srov Adrian von Arburg a Tomáš Staněk, eds., Vysídlení Němců a promény českého pohraniči 1945-1951: Dokumenty z českých archivủ. Díl I: Češi a Němci do roku 1945 - Úvod k edici (Středokluky: Zdeněk Susa, 2010); Adrian von Arburg a Tomáš Staněk, eds., Vysídlení Němců a proměny českého pohraničí 1945-1951: Dokumenty z českých archivů. Díl II, sv. 1: Duben - srpen/září 1945: „Divoký odsun“ a počátky osídlování (Středokluky: Zdeněk Susa, 2011); Adrian von Arburg a Tomáš Staněk, eds., Vysídlení Němců a proměny českého pohraniči 1945-1951 Dokumenty z českých archivů. Díl II, sv. 2: Srpen/záŕí - prosinec 1945: Příprava organizovaného odsunu a postup osídlování (Středokluky: Zdeněk Susa, 2014); Adrian von Arburg a Tomáš Staněk, eds., Vysídlení Němců a proměny českého pohraničí 1945-1951: Dokumenty z českých archivů. Díl II, sv. 3: Akty hromadného násilí v roce 1945 a jejich vyšetřování (Středokluky: Zdeněk Susa, 2010).

${ }^{8}$ Vedle pramenných edic viz např. paměti osadníka Nové Vísky, nyní uložené v Oblastním muzeu (dále OM) v Chomutově, nebo Kronika města Vejprty 1945-1955, která je uložena na Městském úřadě Vejprty.

9 Petra Papírníková, „Činnost internačního střediska v Chomutově v letech 1945-1947“ (diplomová práce, Univerzita Jana Evangelisty Purkyně, Ústí nad Labem, 1998); Jaroslav Santner, „Odsun Němců z Kadaňska 1945-1947“ (diplomová práce, Univerzita Jana Evangelisty Purkyně, Ústí nad Labem, 1996); Petr Šulka „Chomutov 1945-48“ (bakalářská práce, Univerzita Karlova, Praha, 2011); David Kovařík, „Demoliční akce v českém pohraničí v letech 1945-1960“ (disertační práce, Masarykova univerzita, Brno, 2009).

10 Oběti komunistického násili v severočeském pohraničí letech 1945-1946. Expozice dokumentů (Praha: FNS, 2006). Jedná se o katalog ke stejnojmenné výstavě, kterou uspořádalo OM v Chomutově roku 2006.
} 
krajinných území a k jejich neplnohodnotné náhradě tzv. rekultivací. Podobu sídel a způsob života rovněž nepříznivě ovlivnilo zřizování JZD a státních statků, které nahradily zemědělskou výrobu provozovanou dř́ve $\mathrm{v}$ přirozených vesnických společenstvích. V okrese Chomutov bylo do roku 1991 zlikvidováno celkem 107 obcí a sídel, ${ }^{11} \mathrm{z}$ větší části pro účely dưlní činnosti, budování popílkovišt elektráren či vodohospodářských staveb, ale zčásti i pro vojenské účely a z důvodu přirozeného dožití obyvatel provázeného vylidňováním venkova a koncentrací obyvatel ve městech.

Perzekuce církví, jejich představitelů i řadových členů, jíž se dopouštěl komunistický režim, se na Chomutovsku projevila velmi výrazně - Ústecký kraj dnes patří mezi nejateističtější regiony České republiky. Přibližně polovina sakrálních staveb zničených v Československu v letech 1945-1989 se nacházela právě v severních Čechách; jen v Ústeckém kraji šlo o 104 kostelů. Přímo v okrese Chomutov bylo zničeno 29 kostelů. ${ }^{12}$ Duchovní obsah běžného života tak ztratil vazbu na staleté spojení s církevní tradicí a nebyl nahrazen jiným, který by stejně intenzivně působil na tradiční lidovou kulturu a na duchovní svět obyvatel.

\section{Postoj k minulosti a kulturnímu dědictví}

Stav historického vědomí současných obyvatel Chomutovska odpovídá uvedeným historickým příčinám a má přímý vliv na tamější podobu kultury vzpomínání. Dnešní demografická situace v Chomutově je utvářena tím, že je zde sdruženo devět etnik: Češi, Slováci, Němci, Židé, Mad'aři, Romové, Rusíni, Ukrajinci a Vietnamci. Naprostá většina $\mathrm{z}$ nich přišla po válce, nemá tudíž v oblasti předky a nemá ani generační vztah k regionu a je bez oficiálních kontaktů na původní německé obyvatelstvo. ${ }^{13} \mathrm{~V}$ důsledku toho existuje jazyková bariéra mezi německým etnikem a ostatními národnostmi; dříve samozřejmá znalost němčiny zmizela vyhnáním a nejnověji preferencí angličtiny. Kulturní dědictví proto nebylo jako německé postrádáno anebo bylo rovnou považováno za odjakživa české. Mezi návštěvníky chomutovského muzea proto zaznívají dotazy: „Proč nám při

11 Zdena Binterová, Historičtí svědkové doby (Perštejn: Zaniklé obce chomutovského regionu, o.p.s., 2000), 445-448.

12 Výstava Zničené kostely severních Čech 1945-1989, OM v Chomutově, 15. 2. - 14. 4. 2012.

13 Německá menšina, která zůstala v Ústeckém kraji po roce 1948, udržovala kontakty s odsunutými (vyhnanými) Němci jen v rámci úzké rodiny. Do roku 1989 tudíž nebyly - i vzhledem ke geopolitické situaci a otevřeným majetkoprávním otázkám - udržovány žádné styky ani s centrálou Sudetoněmeckého krajanského sdružení v Mnichově, ani s místními organizacemi sdružujícími Němce z Chomutova (Heimatkreis Komotau), Kadaně, Doupova (Heimatkreis Kaaden-Duppau), popř. Mostu (Heimatkreis Brüx). 
výstavách ukazujete německé dokumenty? Proč bychom se tím měli zabývat? Vždyt je to tak dávno.“

Kromě vymezení výše uvedených objektivních faktorů považuji za nezbytné klást si další otázky. Co konkrétně znamená pečovat o německé kulturní dědictví? Jaké jsou výsledky, jaké vidíme problémy? Zde je třeba poukázat na zásadní rozdíl mezi působením muzea jako pamětové instituce $\mathrm{v}$ pohraničních okresech bývalých německojazyčných oblastí a v českém vnitrozemí. Důvodem jsou desetiletí poválečného vývoje, která zásadním způsobem ovlivnila situaci, jež panovala na Chomutovsku po roce 1989.

Jak je to $s$ německým kulturním dědictvím $v$ pohraničí dnes? Zde je třeba z pohledu kultury vzpomínání upozornit na úzkou paralelu mezi péčí o německé kulturní dědictví a péčí o tzv. tradiční lidovou kulturu chápanou jako kulturní statek. $V$ pohraničí je s památkovou péčí spojena faktická, i když někdy nevědomá péče o německé kulturní dědictví hmotné, aniž by se vždy zmiňoval jeho německý původ. U živé, nehmotné tradiční lidové kultury vyvstává v důsledku vyhnání a nuceného vysídlení řada nezodpovězených otázek, jež úzce souvisejí s kulturou vzpomínání. Je tradice vázána na konkrétní nositele? Lze ji přenést s lidmi jinam? Je tradice vázána na určité etnikum, a pokud ano, do jaké míry? Smíme považovat něco většinově spojeného s jiným jazykovým a hodnotovým obsahem za svou tradici? Lze ji znovu oživit pouze ze zprostředkovaných informací o ní? Máme se pracně dobírat původního obsahu, tak jak to činíme, nebo se smírit s multietnicitou nových obyvatel a pěstovat široký vějiŕ lidových tradic jednotlivých národnostních menšin včetně tak exotických jako vietnamská, aniž bychom si je osvojili? Je otázkou, zda lze za těchto podmínek vůbec hovořit o recepci lidové kultury a kultury vzpomínání širokými vrstvami obyvatel v její přirozené a dlouhodobě utvářené podobě.

Nedílnou, avšak specifickou součástí kulturního dědictví je péče o tzv. nehmotné kulturní statky jako součást živé a vyvíjející se tradiční lidové kultury. Na tento dynamický aspekt výslovně upozorňuje Úmluva o zachování nemateriálního kulturního dědictví UNESCO, která byla přijata roku 2003 a která v České republice začala platit v květnu 2009: „Nemateriálním kulturním dědictvím“ se rozumí zkušenosti, znázornění, vyjádření, znalosti, dovednosti, jakož i nástroje, předměty, artefakty a kulturní prostory s nimi související, které společenství, skupiny a v některých př́padech též jednotlivci považují za součást svého kulturního dědictví.“14

14 Úmluva o zachování nemateriálního kulturního dědictví (Paříž, 17. 10. 2003), čl. 2, odst. 1, Ministerstvo kultury ČR, https://www.mkcr.cz/umluva-o-zachovani-nematerialniho-kulturniho -dedictvi-300.html. Všechna zvýraznění provedl autor. 
K naplnění cílů této úmluvy schválila česká vláda opakovaně materiál nazvaný Koncepce účinnější péče o tradiční lidovou kulturu v České republice. Poslední koncepce je platná pro období let 2016 až $2020 .^{15}$

$S$ tradiční lidovou kulturou menšin ani územně a společensky diferencovaným vývojem ovšem tento vládní dokument nepočítá. Koncepce je pojata jako národní, tj. česká, a o specifických potřebách menšin se proto vůbec nezmiňuje. Jak zacházet s jejich tradiční kulturou není řečeno ani v metodických pokynech. ${ }^{16}$

Výzkumem tradiční lidové kultury a péčí o ni na území České republiky se má zabývat Národní ústav lidové kultury. ${ }^{17} \mathrm{Na}$ jeho webu ale nenajdeme žádný odkaz na menšinové komunity. Má proto cenu se ptát: Má pro naplnění jmenované mezinárodní úmluvy význam ono přerušení tradičního německého osídlení a výměna obyvatelstva, resp. nedokončený pokus o náhradu německých obyvatel, který se nesmazatelně projevil právě na podobě „kulturní krajiny“, př́ípadně „kultury krajiny“? Vztahuje se úmluva i na kulturu vzpomínání, a je stát tudíž povinen ji podporovat? Činí tak?

\section{Kultura vzpomínání v činnosti Oblastního muzea v Chomutově}

Není třeba hovořit detailně o všech formách činnosti Oblastního muzea v Chomutově. Jsou jimi státem a samosprávnými orgány Ústeckého kraje organizovaná a finančně podporovaná péče o muzejní sbírky a jejich zpř́stupnění veřejnosti, dále zapojení do aktivit obcí, občanských sdružení a jednotlivců, kooperace s dalšími pamětovými institucemi a akademickými pracovišti a také spolupráce s organizacemi německé menšiny a krajanskou obcí. Připomeňme jen, že využití sbírek a poznatků získaných prostřednictvím muzejních výstav, programů, publikací, stejně jako poskytování informací získaných studiem sbírek nebo prostředí, z něhož jsou získávány, tedy obsáhlý kulturní servis a zapojení muzea do veřejného života, jsou veřejnou službou, uloženou zákonem č. 122/2000 Sb. o sbírkách muzejní povahy. ${ }^{18}$

15 Usnesení vlády České republiky ze dne 13. 1. 2016 č. 10 ke Koncepci účinnější péče o tradiční lidovou kulturu v České republice na období 2016-2020, Ministerstvo kultury ČR, https:// www.mkcr.cz/koncepce-ucinnejsi-pece-o-tradicni-lidovou-kulturu-v-ceske-republiky-na-leta -2016-az-2020-1108.html.

16 Viz Vzorová náplň činnosti regionálního odborného pracoviště pro péči o tradičnílidovou kulturu, Ministerstvo kultury ČR, https://www.mkcr.cz/regionalni-odborna-pracoviste-pro-peci-o-tradicni -lidovou-kulturu-v-krajich-369.html.

17 Srov. Zřizovací listina státní příspěvkové organizace Národní ústav lidové kultury ze dne 19. 12. 2008, http://www.nulk.cz/wp-content/uploads/2017/03/zrizovaci_listina2009.pdf.

18 Zákon o ochraně sbírek muzejní povahy a o změně některých dalších zákonů č. 122/2000 Sb., Sbirka zákonů ČR, částka 36 (2000). 
S ohledem na téma kultury vzpomínání je třeba zmínit především praktické zkušenosti s reflexí společné minulosti v institucionální kooperaci Čechů a Němců, která se naplňuje společnými přeshraničními projekty, muzejními expozicemi, výstavami a doprovodnými akcemi. Muzea mají vytvářet obraz minulosti, což v př́ípadě pohraničí znamená pracovat i na poli německého kulturního dědictví. To nelze bez spolupráce s Němci, at už místními (německou menšinou), původními (krajanskou obcí) nebo sousedícími (Sasy). Krušné hory byly historicky jeden celek propojený obchodními, hospodářskými, sociálními, náboženskými i kulturními vazbami. ${ }^{19}$ Výrazem toho je např. společný česko-saský projekt Hornické kulturní krajiny Erzgebirge/Krušnohoří, usilující o zápis do seznamu světového kulturního dědictví UNESCO. ${ }^{20}$ Dnes ovšem za sudetské Němce v naprosté většině hovoří Češi, př́ípadně si česká strana projektuje do jejich role Sasy.

Kooperace Čechů a Němců v oblasti muzejní práce se realizovala na několika úrovních. Jako velmi př́nosné se ukázaly být kontakty s muzei v saských městech Annaberg-Buchholz, Schlettau, Marienberg a Chemnitz, jež umožnily nejen výměnu informací a studijní pobyty, ale i společné přeshraniční projekty, výstavy a odborné konference. Kromě toho oblastní muzeum v Chomutově navázalo spolupráci také s menšinovými organizacemi, jako jsou Kulturverband der Bürger deutscher Nationalität in der Tschechischen Republik nebo Shromáždění německých spolků v České republice, a podporuje aktivity Výboru pro národnostní menšiny zrrízeného městem Chomutov. Tato kooperace má především formu badatelské a přednáškové činnosti. Dále muzeum spolupracuje rovněž s krajanskými organizacemi, jež sdružují bývalé německé obyvatele Chomutova. Této spolupráce se účastní jak lokální organizace odkazující na místní původ svých členů (tzv. Heimatkreise), tak ústředí Sudetoněmeckého krajanského sdružení v Mnichově a jeho zastoupení v Praze.

Řadu témat vztahujících se k německým obyvatelům Chomutovska jsme přiblízili vydáváním vlastních publikací. Roku 2002 to byly tituly Obce chomutovského okresu; v roce 2003 Heraldické a nápisové památky Chomutovska; v roce 2004 Př́sečnice zatopená, ale nezapomenutá; v roce 2005 pak Kadaň mezi středověkem a novověkem, Zaniklé obce Doupovska od A do Ž a německá verze Verschwundene Orte der Duppauer Gebirges von A bis Z, Miniatury chomutovské sbirky; v roce

${ }^{19}$ Srov. např. Tomáš Karel a Alžběta Kratochvílová, eds., Proměny montánní krajiny. Historické sídelní a montánni struktury Krušnohoři (Loket: Národní památkový ústav, 2013).

20 Podrobněji viz „Krušné hory na cestě na Seznam světového dědictví UNESCO“, Montanregion Krušné hory - Erzgebirge, o.p.s., http://www.montanregion.cz/cs/nominace-unesco.html. 
2007 dále Tajnosti depozitárư a Portrétní miniatury chomutovské sbirky; v roce 2008 České objekty Ströherské sbirky; v roce 2009 Lois Zimmermann; v roce 2012 sborník Centrum krušnohorského lidového umèni; v roce 2013 Staré cesty na Chomutovsku a Opevnèné kostely na Chomutovsku; v roce 2014 V̌semu svètu na útěchu. Sochařství a malírství na Chomutovsku a Kadaňsku 1350-1590 a její německá verze; v roce 2014 3D-publikace Nèmecko-česká zemská výstava Chomutov 1913; a konečně v roce 2015 sborník mezinárodní konference Josef Opitz a umění na Chomutovsku a Kadaňsku 1350-1590.

Specifický charakter měly publikace v dokumentační edici Materiály a studie. V roce 2004 v ní vyšly Účelové známky okresu Chomutov (Chomutovska a Kadaňska); v roce 2005 Lichenoflóra prírodní památky Kokrháč; v roce 2005 Zaniklá železniční trat'Křimov-Reitzenhain; v roce 2005 sborník Zárící minulost; $\mathrm{v}$ roce 2007 Kostel svaté Kateřiny $v$ Chomutově; v roce 2008 Ignác Jan Ehrenwerth; $\mathrm{v}$ roce 2010 Vzpomínky z mého života; a v roce 2013 Zdokumentování dưlního dila u obce Želina na Kadaňsku.

K vybraným výstavám jsme zpracovali většinou dvojjazyčné katalogy. V roce 2002 to bylo k výstavě Chomutov a okoli na starých mapách českých zemi; v roce 2004 Lod'pripravit k boji; v roce 2005 Gustav Hodek, pravý vlasti syn a jeho Pètipsy, Kuriozity z muzeí Ústeckého kraje, Zárící minulost, Nový svět na starých mapách, Vláda vécí Tvých; v roce 2006 pak Prof. Dr. Franz Josefrytír von Gerstner - tvưrce moderního inženýrského myšleni; v roce 2007 Tenkrát v Chomutově; v roce 2008 Chomutovský starosta JUDr. Ernst Storch, Afrika a Orient Rainera Kreissla; v roce 2009 Nekonečné vteřiny; v roce 2011 Svět Krušných hor; v roce 2012 Christian Lehmann, kronikár Krušných hor; v roce 2015 Čechy/Böhmen - domov i Heimat; a konečně v roce 2017 výstava Hans Kudlich, osvoboditel sedlákủ. 21

Těžiště muzejní práce pro širokou veřejnost je třeba hledat ve stálých expozicích a krátkodobých výstavách. Jako konkrétní příklad proto uvádíme celkovou bilanci výstav Oblastního muzea $v$ Chomutově od počátku tisíciletí s vyčíslením podílu výstav, které se nějakým způsobem týkaly německého kulturního dědictví. Více než padesátiprocentní podíl takových výstav je přesvědčivým dokladem jejich tematické aktuálnosti a reflektuje i zájem o ně ze strany chomutovské veřejnosti.

${ }^{21}$ Podrobný soupis viz Stanislav Děd, Příloha Koncepce rozvoje a řízení Oblastního muzea v Chomutově prŕspěvková organizace pro výběrové řízení na funkci ředitele/ky Oblastního muzea v Chomutově, vypsané usnesením Rady Ústeckého kraje č. 048/13R/2017 ze dne 3. 5. 2017. Rukopis v držení autora. 
Tab. 1: Výstavy pořádané Oblastním muzeem v Chomutově v letech 2001-2017

\begin{tabular}{|c|c|c|c|}
\hline \multirow{2}{*}{ Rok } & \multirow{2}{*}{ Počet výstav } & Z toho výstavy na téma německého kulturního dědictví \\
\cline { 3 - 4 } & & Počet & Podíl na celkovém počtu \\
\hline 2001 & 10 & 2 & $20 \%$ \\
\hline 2002 & 17 & 10 & $59 \%$ \\
\hline 2003 & 16 & 5 & $31 \%$ \\
\hline 2004 & 16 & 5 & $31 \%$ \\
\hline 2005 & 16 & 9 & $56 \%$ \\
\hline 2006 & 12 & 7 & $58 \%$ \\
\hline 2007 & 17 & 10 & $59 \%$ \\
\hline 2008 & 17 & 8 & $47 \%$ \\
\hline 2009 & 15 & 10 & $67 \%$ \\
\hline 2010 & 16 & 5 & $31 \%$ \\
\hline 2011 & 18 & 11 & $61 \%$ \\
\hline 2012 & 16 & 9 & $56 \%$ \\
\hline 2013 & 12 & 9 & $75 \%$ \\
\hline 2014 & 20 & 14 & $70 \%$ \\
\hline 2015 & 14 & 7 & $50 \%$ \\
\hline 2016 & 13 & 7 & $54 \%$ \\
\hline 2017 & 16 & 9 & $56 \%$ \\
\hline $2001-2017$ & 261 & 137 & 5 \\
\hline celkem & & 5 & \\
\hline & & 5 & \\
\hline
\end{tabular}

Zdroj: Sestaveno na základě Ročních výkazů o muzeu a galerii (muzeu výtvarných umění) za roky 2001-2017; výkazy uloženy v OM v Chomutově.

Vyjmenovat všech 137 výstav není samozřejmě možné, shrňme proto alespoň několik jejich obecných přínosů. Výstavy především objevily velké postavy regionální historie, které byly v naprosté většině neznámy či pozapomenuty nebo byly poznamenány tendenčními propagandistickými postoji, namátkou F. J. Gerstnera nebo Jiř́ího Popela z Lobkowicz. Výstavy dále poskytly př́ležitost ke spolupráci s národními institucemi (jako s Národním divadlem na projektu Theodora Veidla) i s mezinárodními institucemi (výstavy o Antonu Endersovi a Josefu Opitzovi) a v putovní formě dokázaly též oslovit řadu návštěvníků v Německu a Rakousku (výstava o Hansu Kudlichovi). Výstavy 
rovněž připomenuly velké události regionální historie: působení řádu německých rytírů a jezuitského řádu, průmyslovou revoluci odehrávající se v druhé polovině 19. století a vrcholící Zemskou výstavou německých Čech v roce 1913 i samotné temné události druhé světové války a následného konce soužití Čechů a Němců. Dlužno říci, že se tak dělo za nebývalého zájmu veřejnosti, v řadě případů s veřejným tříbením rozdílných názorů. To bylo ostatně smyslem pořádání těchto akcí se snahou poskytnout nezkreslený obraz místní historie, např́íklad výstavami o vztazích Čechů a Němců v květnu a červnu $1945^{22}$ nebo o rodině Hohenlohe-Langenburg, téměř výhradně negativně spojované s mnichovskou dohodou. ${ }^{23}$ Jejich autoři přitom vycházeli z přesvědčení, že individuum a individuální lidský osud jsou hodny respektu v každé době, že nikoli občané jsou majetkem státu, ale že stát je výtvorem svých občanů a že nikdo nemá právo být ve jménu velkých politických rozhodnutí zbaven své tváře, svého individuálního života, stát se kolečkem v soukolí.

Vzájemné propojení Čechů, sudetských Němců a Sasů ilustrují v muzeu i dvě stěžejní stálé expozice. První z nich, nazvaná Svět Krušných hor, byla vytvořena ve spolupráci s muzeem v saském městě Annaberg-Buchholz. Nabízí jedinečnou expozici tradičního umění lidových hraček, vánočních a zvykoslovných předmětů, sakrálních předmětů a lidových řemesel ze sbírky dr. Eriky Pohl-Ströher, švýcarské sběratelky původem z Krušných hor. ${ }^{24}$ Druhá stálá expozice, věnovaná gotickému a renesančnímu sochařství a malîrství na Chomutovsku a Kadaňsku z období let 1350-1590, má svůj základ již v roce 1928 a navazuje na dílo velkého německého kunsthistorika Josefa Opitze. ${ }^{25}$

Př́kladů spojení činnosti muzea s bohatou činností obcí, občanských sdružení a jednotlivců na poli nemateriálního kulturního dědictví je mnoho. Patří mezi ně výstavy, přednášky, badatelská činnost, publicistika, práce $\mathrm{v}$ terénu, obnova a péče o památníky a o hřbitovy, diskusní setkání, práce s mládeží i projekty paměti. V této souvislosti chci uvést alespoň některá jména, bez nichž by nic z toho nebylo: obnovitel památek na horských stezkách Joachim Baldauf; organizátor

22 Výstava „Tenkrát v Chomutově“, OM v Chomutově, 19. 4. - 10. 6. 2007.

${ }^{23}$ Výstava „Rodina Hohenlohe-Langenburg na Červeném Hrádku“, OM v Chomutově, 20. 4. - 7.7. 2013.

${ }^{24}$ Expozice „Svět Krušných hor“ byla v OM v Chomutově slavnostně otevřena 7. 5. 2011. Podrobněji viz „Svět Krušných hor, stálá expozice“, OM v Chomutově, https://www.muzeumchomutov.cz /aktualne/stale-expozice/dum-jiriho-popela-1/svet-krusnych-hor/.

25 Expozice „Všemu světu na útěchu“ byla OM v Chomutově zpřístupněna 17. 10. 2012 a nahradila tak předchozí expozici z osmdesátých let 20. století. Více viz „Všemu světu na útěchu. Sochařství a malî́ství na Chomutovsku a Kadaňsku (1350-1590)“, OM v Chomutově, https://www.muzeum chomutov.cz/aktualne/stale-expozice/radnice/vsemu-svetu-na-utechu-socharstvi-a-malirstvi/. 
krajanských vztahů k domovu Petr Barton; etnolog a dokumentátor Hernán Benitez-Jump; autorka místopisných monografií a důvěrnice krajanských spolků Zdena Binterová; historik a udržovatel osobních kontaktů Michal Bečvář; pečovatel místního krajanského sdružení a autor vlastivědných prací Gerald Bretfeld; dále Ulf Brossmann; kunsthistorička a archivářka rodu Margarete Buquoy; pečovatelka o tradiční kulturu Zuzana Finger; malír a inspirátor interdisciplinárních projektů Peter Fischerbauer; František Foltýn; organizátorka Hedwig Gemmrig; regionalista a obnovitel církevních památek Alois Harasko; zprostředkovatel starých místních tradic mládeži Antonín Herzán; historik, pedagog a kadaňský patriot Petr Hlaváček; podporovatel místních kulturních projektů a starosta obce Boleboř Jan Juřina; obnovitel vesnického kostela, památek a vztahu k nim František Kabát; historička literatury Anna Knechtel; badatel a přepisovatel starých místních kronik do současného jazyka a písma Ottmar Kreissl; manželé Kubinovi; starosta Kadaně Jiří Kulhánek; vlastivědný badatel a organizátor Otto Macák; pedagog a vychovatel mládeže Josef März; historik a organizátor Petr Mikšíček; badatel o historii města Př́sečnice a organizátor novoročních setkání na Špičáku Hans Müller; dále sdružení Omnium, zabývající se péčí o památky a hřbitovy; mecenáš a organizátor terénní práce Josef Pelant; dobrovolný kustod muzea Böhmerwaldmuseum Wien und Erzgebirger Heimatstube Gernot Peter; Jürgen Schmidt; podporovatelé vlastivědné práce manželé Schmitzerovi; pečovatel krajanského sdružení Kurt Stoupa; obnovitel historie a kulturního života na vesnici Josef Šporgy; pamětník a besedník Heinz Wenisch; a mnoho dalších.

Činnost jednotlivců, zejména těch, kteří přicházeli nejen na samém počátku navazování kontaktů po roce 1989, ale mají zájem o spolupráci dodnes, však není i přes dobré úmysly vždy přijímána kladně a naráží na nepochopení, nedůvěru a podezíravost. Bývalí němečtí obyvatelé Chomutovska či jejich potomci doplácejí také na neznalost českých psychických bariér ve vztahu k Němcům i na malé sebevědomí místních obyvatel, možná i na špatné svědomí, což stojí někde $\mathrm{v}$ pozadí odmítavých postojů zejména oficiálních orgánů na úrovni kraje i státu. $V$ řadě prŕpadů jsou prrímo odmítáni s tím, že „Němci se nám tu přece nebudou roztahovat“. Přitom základní, prvotní záměr bývalých německých obyvatel je právě ona natažená ruka k vzájemným kontaktům, respekt k historii, $\mathrm{k}$ místopisu a k uchování paměti krajiny. $V$ některých př́padech je na překážku pouhý střet aktivity německých iniciátorů s pasivitou české strany, vedoucí až k absurdním výmluvám na nutnost úředního postupu či na jejich špatnou češtinu anebo k požadavku, aby byl u památníků obnovených dobrovolníky ze vzdálených míst zajišš̌n pravidelný úklid po návštěvnících. 
Za mimořádný úspěch a potřebný precedent do budoucna lze proto považovat fakt, že se Oblastnímu muzeu v Chomutově podařilo za členku Komise pro tradiční lidovou kulturu Ústeckého kraje prosadit dr. Zuzanu Finger, referentku pro lidovou kulturu Sudetoněmeckého krajanského sdružení. Je to možná první případ, kdy je krajanské sdružení prímo zapojeno do činnosti českého oficiálního orgánu a může v něm kvalifikovaně zastupovat sudetoněmeckou kulturu.

\section{Situace německých hřbitovů}

Do působnosti Oblastního muzea v Chomutově spadá i specifická oblast německého kulturního dědictví a kultury vzpomínání, kterou představují hřbitovy s německými hroby a náhrobky. Situaci německých hřbitovů na Chomutovsku lze s plnou vážností označit za tragickou. Muzeum ji dlouhodobě dokumentuje na stavu sedmdesáti hřbitovů. ${ }^{26}$ Podle jejich stavu rozlišuje pět kategorií:

1) hřbitovy pietně upravené: Březno (Priessen), České Hamry (Böhmisch Hammer), Droužkovice (Trauschkowitz) - viz Obr. 1;

2) hřbitovy udržované, ale částečně poškozené různým stupněm likvidace německých náhrobků: Boleboř (Göttersdorf), Hrušovany (Hruschowan), Kalek (Kallich), Místo (Platz), Pětipsy (Fünfhunden), Údlice (Eidlitz), Výsluní (Sonnenberg) - viz Obr. 2;

3) hřbitovy katastrofálně zdevastované: Chomutov-Horní Ves, Louchov (Laucha), Měděnec (Kupferberg), Křimov (Krima), Podletice (Podletitz), Přečáply (Pritschapel), Všestudy (Schössl), Zásada (Sosau), židovský hřbitov v Údlici (Eidlitz) - viz Obr. 3;

4) hřbitovy vyčištěné totálním tzv. „úklidem“, během něhož byly náhrobky zlikvidovány nebo vyhozeny za zed': Mikulovice (Niklasdorf), Hora Sv. Šebestiána (Sebastiansberg), městský a židovský hřbitov v Chomutově (Komotau), Úhoštany (Atschau), Bílence (Bielenz); Libědice (Libotitz) - viz Obr. 4;

5) hřbitovy zcela zaniklé: Dolina (Dörnsdorf), Menhartice (Märzdorf), Pyšná (Stolzenhan), Př́́sečnice (Pressnitz) - viz Obr. 5.

Zvláštním př́ípadem jsou hřbitovy ve vojenském prostoru Hradiště: Doupov (Duppau), Bražec (Bergles), Lochotín (Lochotin), Svatobor (Zwetbau), Ždár (Saar) - viz Obr. 6.

26 Výroční zprávy Oblastního muzea v Chomutově v za roky 2014-2017, viz „Výroční zprávy“, OM v Chomutově, https://www.muzeumchomutov.cz/publikace/zpravy-o-cinnosti/. 


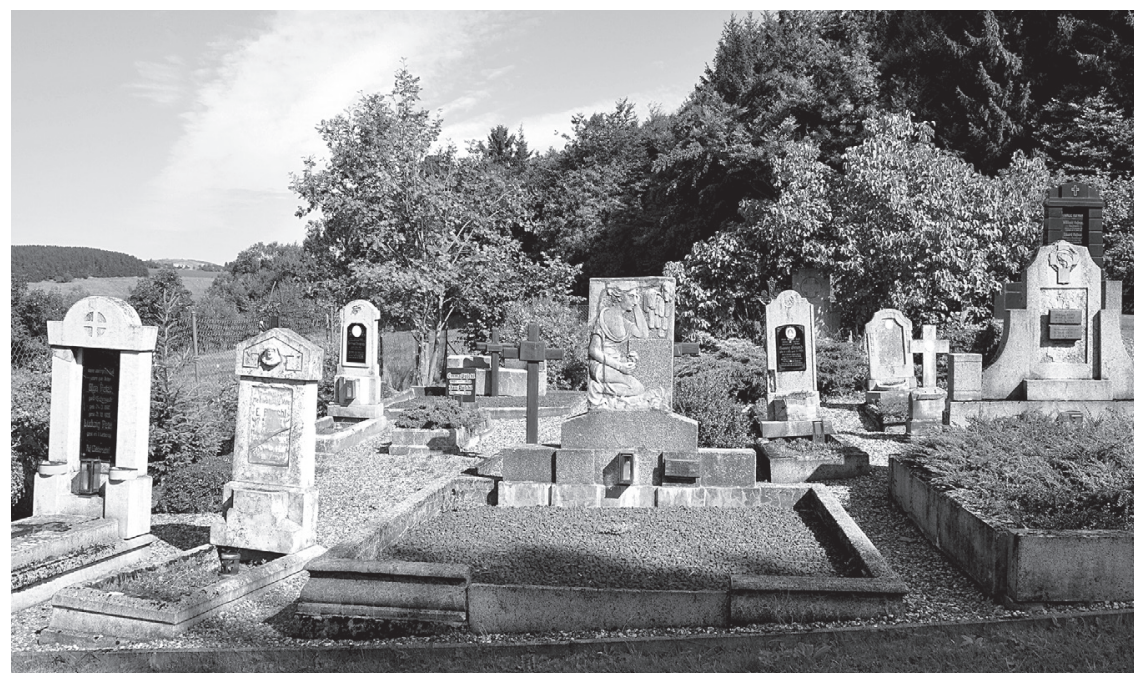

Obrázek 1: Hřbitov v Českých Hamrech

Autor: Hugo Sedláček, 2016

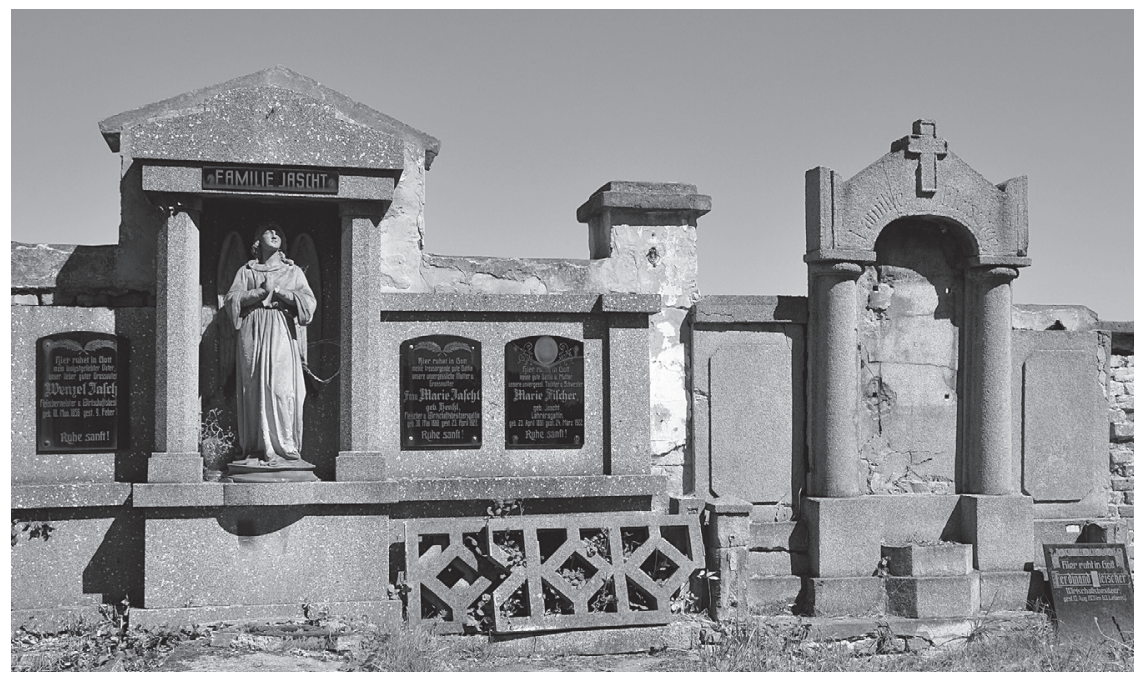

Obrázek 2: Hřbitov v Údlicích

Autor: Hugo Sedláček, 2016 


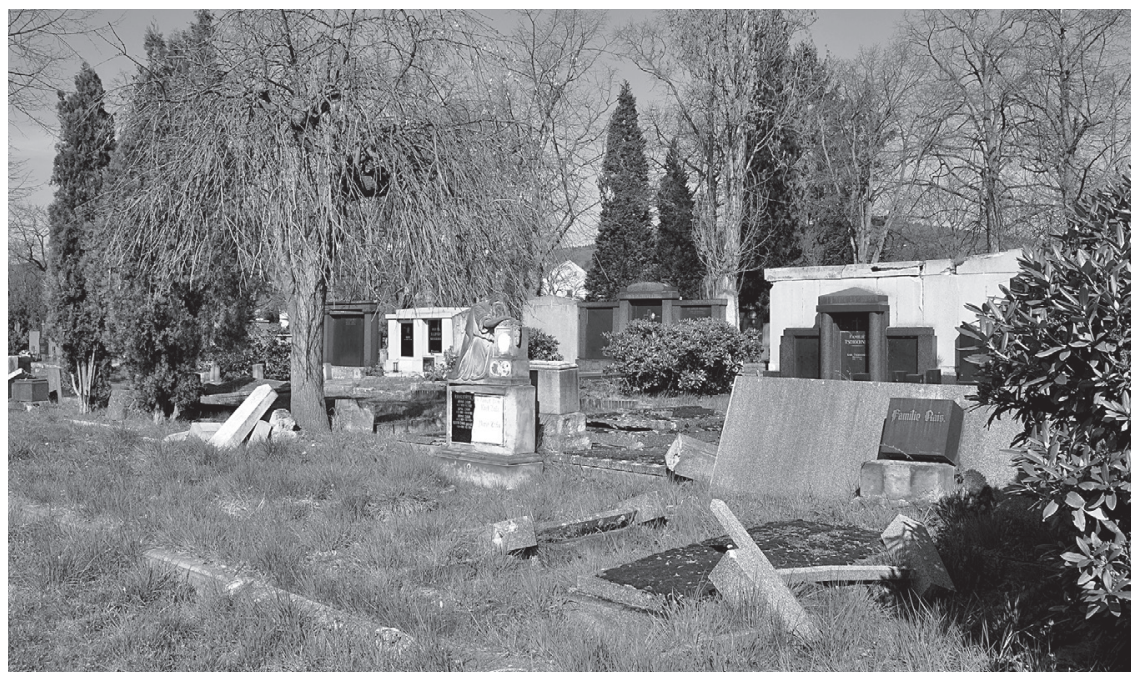

Obrázek 3: Hřbitov v Chomutově-Horní Vsi

Autor: Hugo Sedláček, 2015

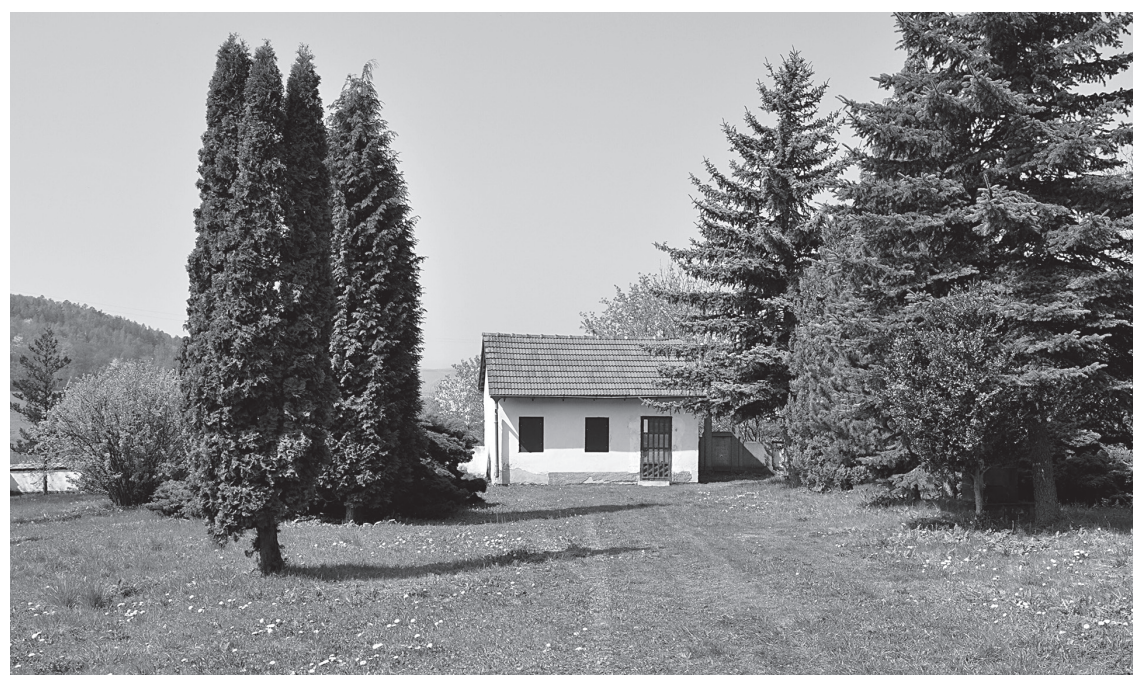

Obrázek 4: Hřbitov v Mikulovicích

Autor: Hugo Sedláček, 2011 


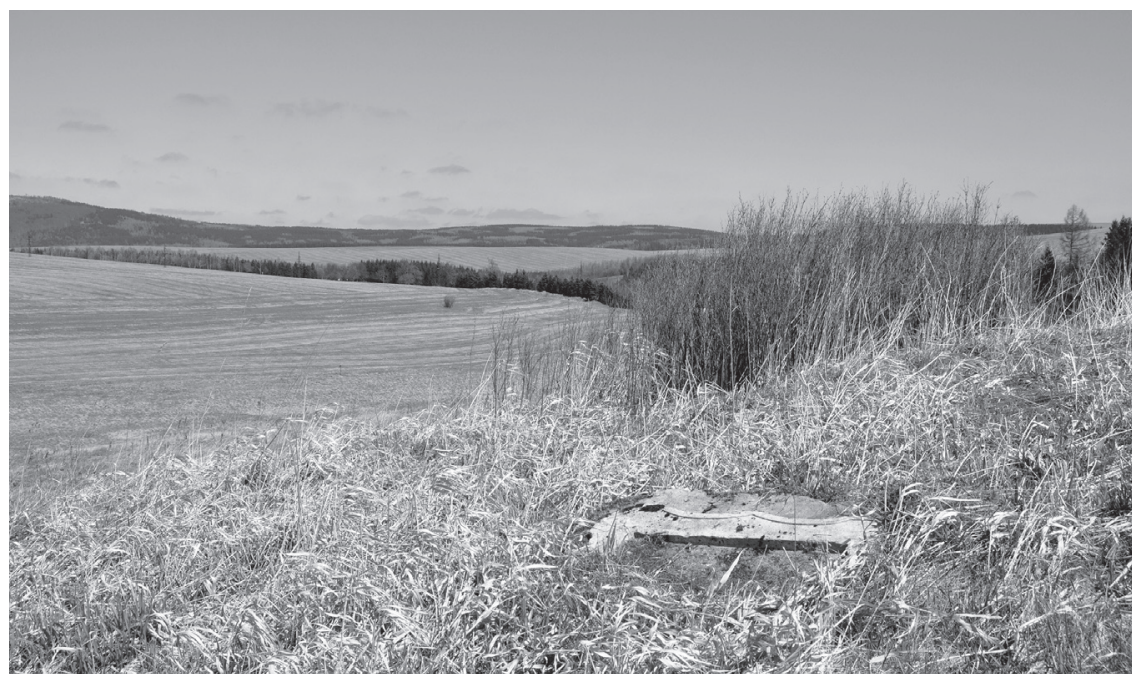

Obrázek 5: Zaniklý hřbitov v Dolině

Autor: Hugo Sedláček, 2016

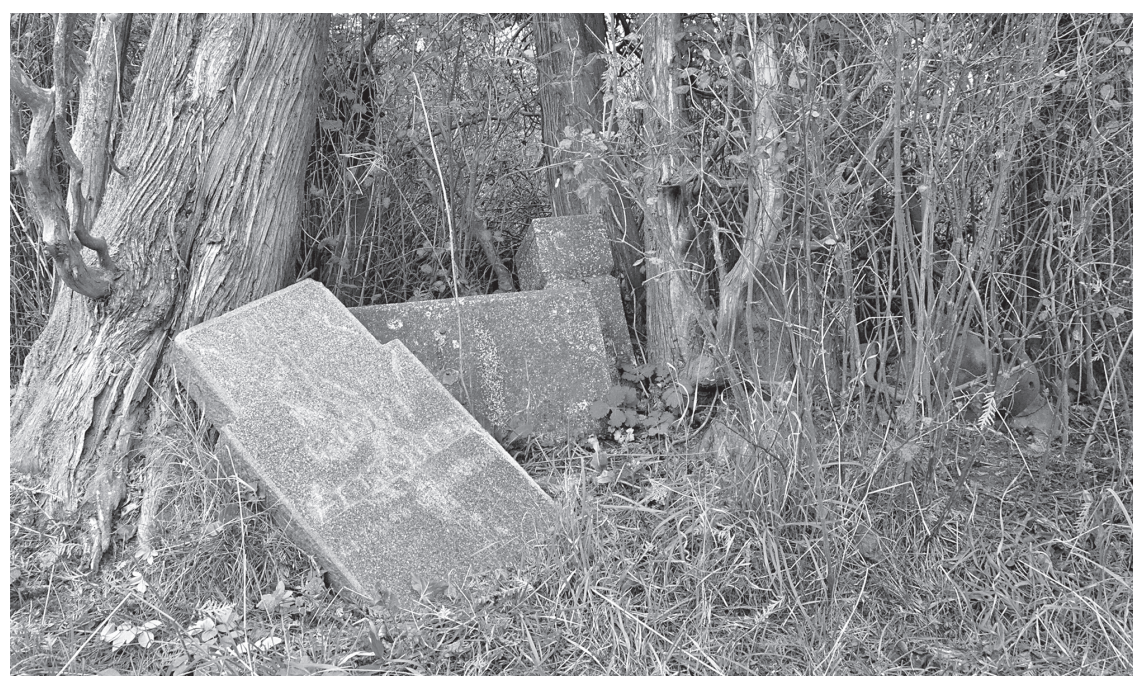

Obrázek 6: Zaniklý hřbitov v Doupově

Autor: Hugo Sedláček, 2015 
Zjištěný stav vedl Oblastní muzeum v Chomutově k rozhodnutí pokusit se situaci aktivně změnit na základě prostého přesvědčení, že chce-li být stát považován za civilizovaný, má povinnost pietně udržovat místa posledního odpočinku minulých generací, lhostejno zda českých nebo německých. Tím je třeba rozumět i podmínky individuální občanské péče, tedy úpravu práv a povinností nejen provozovatelů pohřebišt', ale i občanů jednotlivců ustanoveními zákona č. 256/2001 Sb. o pohřebnictví, příp. občanským zákoníkem.

Český stát rozhodnutím o vyhnání, resp. nuceném vysídlení Němců převzal nejen skutečný majetek a - často pofidérní - výhody a zisky s tímto přesunem dočasně spojené. Převzal tím i trvalé povinnosti a odpovědnost, v neposlední řadě také povinnost pečovat o hřbitovy a hroby. Převzal ji i proto, že bývalým vlastníkům znemožnil o ně rádně pečovat tím, že na desítky let uzavřel hranice a upřel tím prakticky celé generaci právo kontaktu s jejími předky. Navíc zabránil tomu, aby si normální vztah k vlasti vytvořila i generace jejich potomků.

Širokou paletou opatření ústředních orgánů v rámci centrálně řízené společnosti, sahající od programu tzv. „čechizace zněmčelých územi“, přes subjektivní rozhodnutí místních funkcionářu a úřadů až po zdánlivě objektivní plánovitá opatření v „celospolečenském zájmu“, navíc za mlčenlivého souhlasu a někde i přispění české veřejnosti, dopustil postupnou devastaci těchto pietních míst.

Porevoluční pokus zákonem č. 256/2001 Sb. o pohřebnictví27 legislativně ošetřit prodeje, rušení a devastaci hrobů a celých hřbitovů pouhým vyvěšením oznámení na vývěsce správy hřbitova je formálním pokusem přeskočit do jakýchsi zdánlivě normálních civilizovaných poměrů, aniž by byly vzaty v úvahu nenapravitelné důsledky období desetiletí přerušených kontaktů a byla přijata speciální opatření na tuto skutečnost reagující. $V$ důsledku přijetí výše uvedeného zákona dochází k rozsáhlé, plošné a zákonem posvěcené likvidaci nejstarších hrobů.

\section{Česko-německá smlouva jako právní nástroj?}

Problém odstraňování náhrobků a rušení hrobů je ovšem i záležitostí bilaterálních vztahů mezi Českou republikou a Spolkovou republikou Německo. Jejich podobu v současnosti upravuje zejména Smlouva o dobrém sousedství a přátelské spolupráci č. 521/1992 Sb., která obecně formuluje cíle v kulturní

27 Zákon o pohřebnictví a o změně některých zákonů č. 256/2001 Sb., Sbírka zákonů ČR, částka 98 (2001). 
oblasti a současně jasně definuje povinnosti státu, které mají být plněny bez ohledu na aktuální politickou reprezentaci. Pro problematiku německých hrobů jsou důležitá zejména tato ustanovení.

Článek 24 česko-německé smlouvy výslovně stanovuje:

(1) Smluvní strany budou spolupracovat při udržování evropského kulturního dědictví a při péči o něj. Zvláštní pozornost budou věnovat péči o památky.

(2) V duchu porozumění a usmírení budou uskutečňovat společné iniciativy v této oblasti.

(3) Budou pečovat zejména o mista a kulturnípamátky, nacházející se na jejich území, připomínajicí dějinné události, kulturní a vědecká díla a tradice druhé strany a umožní k nim svobodný a nerušený přístup. Uvedená místa a kulturní památky jsou zákonem chráněny.

Článek 30 smlouvy pak zní:

(1) Smluvní strany prohlašují, že československé a německé hroby, nacházejicí se na jejich území, budou stejným zpưsobem uctívány a chráněny; péče o ně bude umožněna.

(2) Hroby československých, respektive německých oběti válek a panování násilí, nacházející se na jejich území, požívají právní ochrany a jsou zachovávány; jejich registrace a péče o ně bude umožněna.

(3) Smluvní strany budou podporovat spolupráci mezi organizacemi, př́slušnými pro péči o tyto hroby. ${ }^{28}$

První impuls k řešení této situace přinesla mezinárodní konference, kterou spoluorganizovalo Oblastní muzeum v Chomutově v květnu $2015^{29}$ a na níž byla česko-německá smlouva představena jako vhodný legislativní nástroj k zastavení devastace hrobů či celých hřbitovi̊. Následovalo oslovení Zemského shromáždění německé menšiny, prezentace podnětu v Radě vlády pro národnostní

${ }^{28}$ Smlouva mezi Spolkovou republikou Německo a Českou a Slovenskou Federativní Republikou o dobrém sousedství a přátelské spolupráci ze dne 27. 2. 1992, Úřad vlády ČR, https: / /www.vlada .cz/assets/media-centrum/aktualne/Smlouva-mezi-Spolkovou-republikou-Nemecko-a-Ceskou -a-Slovenskou-Federativni-Republikou-o-dobrem-sousedstvi-a-pratelske-spolupraci.pdf. Všechna zvýraznění provedl autor. Smlouva vstoupila v platnost 14. záŕí 1992.

29 První konference „Monumenta viva - péče o kulturní dědictví v oblastech bývalých Sudet“ se konala v Chomutově ve dnech 11. a 12. května 2015. 
menšiny v únoru $2016,{ }^{30}$ ustavení pracovní skupiny pro funerálie ${ }^{31}$ a uspořádání další mezinárodní konference v dubnu 2016.32

Do pracovní skupiny byli pozváni zástupci Ministerstva kultury ČR, Ministerstva pro místní rozvoj ČR, Ministerstva financí ČR, Ministerstva zahraničních věcí ČR, Ministerstva zemědělství ČR, Svazu měst a obcí ČR, Asociace krajů ČR, německé a ruské menšiny, židovské komunity, sekretariát Rady vlády a ředitel Oblastního muzea v Chomutově. ${ }^{33}$

Při pěti výjezdech do pohraničí jednala pracovní skupina za účasti hejtmanů a náměstkyň ministrů. Se starosty navštívila hřbitovy dvaceti obcí. Ukázalo se, že způsob, jakým se většina správců hřbitovů s neuspokojivým stavem staví k tomuto problému, vykazuje značnou setrvačnost myšlení bez ohledu na společensko-politické změny, $\mathrm{k}$ nimž došlo po roce 1989. Z legislativních předpisů akceptují správci výhradně zákon o pohřebnictví z roku 2001, a tudíž vyvěšením jakéhokoli upozornění na hřbitovní vývěsce považují veškeré své povinnosti za splněné. O existenci česko-německé smlouvy sice vědí, ale její text neznají a považují ji za nezávaznou. Německy zpravidla vůbec nemluví a k německým krajanům nejsou př́liš vstřícní. Za základní povinnost považují vybírání poplatků za pronájem hrobového místa, jejichž neuhrazení umožňuje likvidaci a prodej náhrobků. Správci nerespektují doporučení, aby neprodávali náhrobky z hrobů s neuhrazeným pronájmem, jestliže jsou k dispozici jiná volná hrobová místa.

\section{Současný stav péče o hřbitovy}

V návaznosti na proběhnuvší místní šetření pracovní skupiny bylo v roce 2016 k řešení situace přijato usnesení Rady vlády pro národnostní menšiny č. 181 následujícího znění:

30 Zápis z jednání Rady vlády pro národnostní menšiny dne 22. 2. 2016 v Praze, Úřad vlády ČR, https://www.vlada.cz/assets/ppov/rnm/jednani-rady/160222_zapis_rada_web_oprava_mv.pdf.

${ }^{31}$ Usnesení č. 174 Rady vlády pro národnostní menšiny ze dne 26. 4. 2016, Úř́ad vlády ČR, https:// www.vlada.cz/cz/ppov/rnm/jednani-rady/jednani-rady-dne-26-dubna-2016-142986.

32 Druhá konference „Monumenta viva - péče o kulturní dědictví v oblastech bývalých Sudet" se konala v Chomutově ve dnech 7. a 8. dubna 2016.

33 Ředitel Oblastního muzea v Chomutově upozorňoval na špatný stav mnohých německých hrobů a na možnosti, jak situaci řešit, také v odborném tisku. Viz Stanislav Děd, „Situace německých hrobů na českých hřbitovech v pohraničí se zřetelem $\mathrm{k}$ česko-německé smlouvě o dobrém sousedství", Památky, príroda, život: vlastivědný čtvrtletník Chomutovska a Kadaňska 48, č. 2 (2016): $16-32$. 
Rada schvaluje informaci o činnosti pracovní skupiny pro řešení situace německých (a dalších) hrobů na hřbitovech v ČR a podporuje vládní novelu zákona o pohřebnictví omezující exhumace. Poukazuje na nedostatečné plnění článků 24 a 30 Česko-německé smlouvy o dobrém sousedství z roku 1992, ve které se český stát zavazuje zajistit uctívání a ochranu opuštěných hrobů. Rada doporučuje svému předsedovi, aby v této věci dopisem oslovil ministryni pro místní rozvoj a doporučil jí zřízení dotačního programu, zaměřeného na veřejná a neveřejná pohřebiště a hřbitovy, včetně zaniklých, v první fázi na evidenci hrobových míst, ve druhé fázi na údržbu hrobových zařízení. Dále [doporučuje - pozn. aut.] oslovit kraje, aby upozornily provozovatele veřejných pohřebišt na povinnost dodržovat ustanovení zákona o pohřebnictví, ve kterém je česko-německá smlouva implementována, a doporučit vydání krajské metodiky o zásadách pietního nakládání s hroby a hřbitovy. Rada schvaluje pokračování pracovní skupiny v činnosti. ${ }^{34}$

Poté započala prríprava Př́ručky pro obce, vycházející z citovaného usnesení Rady vlády, ustanovení česko-německé smlouvy a doporučení koordinační rady Česko-německého diskusního fóra, která prošla připomínkovým řízením. Oblastní muzeum v Chomutově poté pořídilo překlad materiálu do němčiny. Péčí Úřadu vlády ČR a Ministerstva pro místní rozvoj ČR vyšla v polovině roku 2017 česká verze příručky v nákladu 600 kusů a německá verze v nákladu 200 kusů, které byly rozeslány krajům. ${ }^{35}$

Otázka historických německých hřbitovů se po letech usilovné práce stala záležitostí, jejíž důležitost a nutnost řešení už nejsou zpochybňovány. Naopak se jí usnesením Rady vlády pro národnostní menšiny a podporou dalších menšin dostalo potřebné vážnosti. Existují samožrejmě i antiteze, které v rámci pracovní skupiny zazněly také, ale po obsáhlé diskusi byly odmítnuty.

Mezi ně patří v prvé řadě argument, že „Němci si musí uvědomit, kdo prohrál válku!". Ten by možná mohl platit jako součást obecné protiněmecké nálady i oficiálních postojů československého státu v roce 1945, ale nikoli o více než 70 let později, kdy existuje jak právní úprava česko-německých vztahů včetně problematiky hrobů, vyjádřená v česko-německé smlouvě v článcích 24 a 30

34 Usnesení č. 181 Rady vlády pro národnostní menšiny ze dne 27. 10. 2016, Úřad vlády ČR, https:// www.vlada.cz/cz/ppov/rnm/jednani-rady/jednani-rady-dne-27--rijna-2016-150230/.

35 Kpéći o opušténé nèmecké a dalši hroby na hřbitovechv Českérepublice. Př́ručka pro obce (Praha: Úřad vlády ČR, 2017), https://www.vlada.cz/assets/ppov/rnm/dokumenty/publikace/2017_06_09 _pece_o_hroby_schvalena_brozura.pdf; Pflege der verlassenen deutschen und anderen Gräber auf Friē $\bar{d}$ öfen der Tschechischen Republik. Handbuch für Gemeinden (Praha: Regierungsamt der Tschechischen Republik, 2017), https://www.vlada.cz/assets/ppov/rnm/dokumenty /publikace/170612_graeber_friedhoefer_handbuch.pdf. 
a v česko-německé deklaraci v článku VII, tak i spojenectví obou zemí dané společným členstvím v Evropské unii a v NATO.

Další takovou tezí je, že ustanovení čl. 30 česko-německé smlouvy konstatující, že „hroby [...] budou stejným způsobem uctívány a chráněny“, samo o sobě ještě nezakládá ochranu hrobů a hřbitovů, pouze stejné zacházení s nimi. Tím ovšem nelze odůvodnit probíhající plošnou fyzickou devastaci historických německých oddělení na českých hřbitovech, obchodování s náhrobky ani nerespektování nesouhlasu druhé smluvní strany s takovým zacházením, vyjádřené mj. v postoji koordinační rady Česko-německého diskusního fóra, ${ }^{36}$ tedy postupů, které rozhodně nejsou ochranou německých hrobů a ke kterým na českých hrobech v Německu nedochází.

Stejně tak je tomu s kazuistikou s pojmy "definice německého hrobu“ a s požadováním přednostního provedení důkladné inventarizace a soupisu hrobů s vyčíslením předpokládaných fiktivních nákladů. Tento postup by ve skutečnosti odsunul jakoukoli změnu zacházení s hroby do blíže neurčené budoucnosti, a tudíž nezastavil permanentní plošnou devastaci, $v$ jejímž důsledku by nakonec nebylo co zachraňovat.

V neposlední řadě také zaznívá názor, že starostové obcí jako provozovatelé pohřebišt musejí v situaci trvalého nedostatku finančních prostředků upřednostnit praktické potřeby obce jako chodníky, kanalizace apod. Tento postoj ovšem nerespektuje jednoduchost přijetí politického rozhodnutí o zastavení devastačních manipulací s německými hroby, nevyžadujícího žádné finanční prostředky, a zakrývá podstatu postoje, který vyžaduje jeho politickou obhajobu. Je totiž motivován jak obavou z postoje veřejnosti, vedoucího k nejistotě znovuzvolení, tak i neúctou k právu a nedostatkem právního vědomí o stejné právní síle zákona i mezinárodní smlouvy, ba i o aplikační přednosti smlouvy.

\section{Závěr}

Ukázali jsme, že v problematice německého kulturního dědictví nejde z pohledu kultury vzpomínání o všeobecnou frázi o hájení kulturního odkazu, ale že aktuální jsou především úvahy, jak ho prakticky realizovat. Za klíčovou otázku je třeba považovat vztah $\mathrm{k}$ jeho pravým původcům, tj. ke stále existující velké komunitě bývalých německých obyvatel českých zemí, kteř́ jsou zjednodušeně označováni za sudetské Němce. Pomalu, často bolestně

36 Stanovisko koordinační rady Česko-německého diskusního fóra k tématu Hřbitovy jako svědkové dějin, Praha, 7. 3. 2002. 
dospíváme k poznání, že německý prvek je součástí české historie, a tudíž i jejího kulturního dědictví.

V muzeu jsme se proto snažili znát i stanoviska bývalých německých obyvatel Chomutovska. Mnohokrát byli součástí týmu připravujícího projekt, publikaci či výstavu. Mnohokrát jsme prezentovali jejich vlastní pohled na zacházení s německým kulturním dědictvím. Udržovali jsme pravidelné styky s místními krajanskými skupinami a veřejně je prezentovali.

Jde o to, zda jsme všude schopni a někdy ochotni hlásit se i mimo okruh odborných pracovníků $\mathrm{k}$ tomu, že v pohraničí, ale i jinde pracujeme s německým kulturním dědictvím, a tuto skutečnost objektivně, bez emocí přiznat a pracovat s ní jako s neskrývaným faktem. Kdo jiný by se měl snažit přinášet objektivní informace oproštěné od politických kontextů a založené na vědeckém poznání než muzea a akademická obec. Nesporně je to náš dluh vůči veřejnosti.

Platí to i pro oblast péče o německé historické hřbitovy, specifické součásti kulturního dědictví. Výjezdy vládou pověřené pracovní skupiny do Ústeckého, Karlovarského, Jihomoravského, Královéhradeckého kraje a do kraje Vysočina ukázaly nejhorší stav hřbitovů v západočeském a severočeském pohraničí a konstatovaly nejodmítavější přístup samosprávy právě v Ústeckém kraji, kde jsou rezidua minulosti zakořeněna programově. $V$ problematice hřbitovů je stále třeba vidět dvě možná řešení. Především je to klasický postup tam, kde ze strany veřejnosti a samospráv existuje pochopení pro závažnost tématu a relativní „dostatek“ partnerských subjektů, využívajících již existující možnosti pro podávání projektových žádostí k Česko-německému fondu budoucnosti nebo pro čerpání financí z omezených grantových prostředků ministerstev, krajů a obcí. Druhé, mimořádné řešení je nutné v oblastech, kde takový postup není možný z důvodu negativního postoje vedení obcí, prríliš vysokého počtu postižených lokalit nebo neexistence subjektů, které by mohly situaci řešit, vzhledem k věkovému složení krajanské obce či vzhledem k rozsahu potřebné sanace, která přesahuje možnosti občanské iniciativy.

Ke zvýšení informovanosti o tom, že existuje právní možnost mimořádného řešení, směřuje i vlastní smysl původního podnětu k možnosti využít stávající aktivní a vymahatelné zákonné povinnosti státu, která vyplývá z mezinárodní smlouvy České republiky se Spolkovou republikou Německo. Nutnost urychleného řešení je vzhledem ke stále pokračující devastaci německých hřbitovů skutečně akutní. Faktické zastavení devastace je v tuto chvíli mnohem potřebnější než hledání finančních prostředků na obnovu hrobů. Při prosazování tohoto požadavku je třeba klást důraz na čl. 24, odst. 1 a čl. 30 česko-německé smlouvy, v níž se obě strany zavázaly k péči o evropské kulturní dědictví, zejména 
o památky připomínající dějinné události a tradice druhé strany. Hřbitovy jsou přitom často posledním viditelným dokladem existence německého etnika a jeho kultury, tradic, osobností, jejich díla, zároveň dokladem a přehlídkou vývoje funerální kultury a uměleckého řemesla a v neposlední řadě také živou knihou historie řady míst na českém území.

\section{Redakční postscriptum}

V souvislosti s výše otišš̌ným príspěvkem nelze nevzpomenout, že problematika česko-německých vztahů se objevuje na stránkách našeho časopisu opakovaně v podobě odborných studií i knižních recenzí. ${ }^{37}$ Jen málo textů se však tohoto tématu dotklo jiným než ryze akademickým způsobem. Stanislav Děd, někdejší ředitel Oblastního muzea v Chomutově, v publikovaném př́íspěvku čerpá ze svých poznatků a zkušeností získaných během svého působení v této pamětové instituci v letech 2001 až 2017. Jakkoli jsou aktivity tohoto regionálního muzea oborově i tematicky velmi různorodé, usiloval Stanislav Děd o to, aby muzejní expozice a sbírky vztahující se k historii zachycovaly minulost Chomutovska v její co možná ucelené podobě. Její nepominutelnou součástí byla existence německého fenoménu, jehož představitelé tvořili do roku 1938 více než osmdesát procent místních obyvatel a po roce 1945 byli z naprosté většiny nuceně vysídleni.

Téma nuceného vysídlení německé menšiny z Československa po řadu desetiletí výrazně ovlivňovalo diskusi o další podobě československo-německých, resp. česko-německých vztahů. Zástupci bývalých německých obyvatel Československa pak debatu rozviřovali svými požadavky domáhajícími se práva na návrat do vlasti a odškodnění za zkonfiskovaný majetek. ${ }^{38}$ Nepřekvapuje proto, že na české straně - zejména v oblastech, z nichž byli českoslovenští občané německé národnosti odsunuti - nebyl o připomínání této skutečnosti valný zájem.

Od nuceného vysídlení této skupiny obyvatel však uplynulo už více než sedm desetiletí a zejména $\mathrm{v}$ posledních dvaceti letech se $\mathrm{v}$ př́istupu $\mathrm{k}$ tomuto tématu

37 Z posledních let srov. např. Petr Šafařík, „Die Edvard Beneš-Bücher der Publizistin Sidonia Dedina: Von einem Ausdruck des problematischen Kanons im Diskurs über den tschechisch-(sudeten) deutschen Themenkomplex“, AUC Studia Territorialia 12, č. 3-4 (2012): 71-106; celé tematické dvojčíslo připravené ve spolupráci s Česko-německou a Slovensko-německou komisí historiků, jež se se zabývalo vztahem médií a společnosti v 19. a 20. století: AUC Studia Territorialia 13, č. 1-2 (2013); a Benjamin Conrad, „Das mehrsprachige Abgeordnetenhaus der Tschechoslowakei in seiner parlamentarischen Praxis 1920-1938“, AUC Studia Territorialia 16, č. 1 (2016): 44-63.

38 Přehledné shrnutí této problematiky nabízí nejnověji Jaroslav Kučera, Mírové uspořádání s Německem. Od protihitlerovské koalice k Česko-německé deklaraci (Praha: Dokořán, 2018), zejm. 311-377. 
mnohé změnilo. Na mezistátní úrovni se tak stalo především díky Česko-německé deklaraci z roku 1997, která zcela nedvojsmyslně konstatovala shodu obou stran na tom, že „nebudou zatěžovat své vztahy politickými a právními otázkami pocházejícími z minulosti “ ${ }^{39} \mathrm{~V}$ rovině odborné reflexe je pak zřejmé, že situace, jež panovala $\mathrm{v}$ českém pohraničí v bezprostředně poválečném období, přestává být redukována čistě na konflikt mezi Čechy a Němci, ale začíná být zkoumána v širším politickém, hospodářském a společenském kontextu. ${ }^{40}$ Zvyšující se časový odstup od událostí let 1945-1947 má nakonec ten důsledek, že počet jejich pamětníků na obou stranách každým rokem klesá. Proměně náhledu na nucené vysídlení a související otázky napomáhá i změna ve stanovách Sudetoněmeckého krajanského sdružení, nejvlivnějšího obhájce zájmů bývalých německých obyvatel Československa. $Z$ cílů uvedených $\mathrm{v}$ jeho stanovách byly v roce 2016 definitivně vyškrtnuty dva pro českou politickou reprezentaci zásadně nepřijatelné požadavky: právní nárok na návrat do staré vlasti a navrácení zkonfiskovaného majetku či jemu odpovídající odškodnění.

Všechny tyto skutečnosti přispívají k tomu, že přítomnost německé menšiny v Československu před rokem 1945 je stále více tematizována také v pracích veřejných pamětových institucí a ve veřejném prostoru obecně. ${ }^{41}$ Polemiku Stanislava Děda, vycházející ze znalosti specifik Ústeckého kraje, proto chápeme právě jako prŕspěvek do této diskuse. Jedním dechem nutno také dodat, že tato diskuse je mimo svůj regionální rozměr a zasazení do rámce česko-německých vztahů také dokladem a velmi dobrou ukázkou existence a působení obecnějšího fenoménu, který se v anglosaském světě prosadil již v osmdesátých letech pod názvem public history.

Text je otištěn v autorské redakci, jejíž součástí je i použitá terminologie. Týká se to zejména pojmů, jež autor volí pro označení samotného procesu, jehož výsledkem bylo praktické vymizení všech německých obyvatel z poválečného československého území, stejně jako pojmenování samotné komunity, již tito př́islušníci vytvořili ve Spolkové republice Německo.

Lucie Filipová a Jan Šír

39 Česko-německá deklarace o vzájemných vztazích a jejich budoucím rozvoji ze dne 21. ledna 1997, čl. IV, Parlament ČR, Poslanecká sněmovna 1996-1998, tisk 12900, část č. 4, http://www.psp.cz /eknih/1996ps/usneseni/u0221.htm.

40 Viz např. Andreas Wiedemann, ,,Pojd's námi budovat pohraniči “. Osídlování a proměna obyvatelstva bývalých Sudet 1945-1952 (Praha: Prostor, 2016). Jedná se o český překlad autorovy německé disertace: Andreas Wiedemann, ,, Komm mit uns das Grenzland aufbauen! " Ansiedlung und neue Strukturen in den ehemaligen Sudetengebieten 1945-1952 (Essen: Klartext, 2007).

${ }^{41}$ Dušan Kováč, Miloš Řezník a Martin Schulze-Wessel, eds., Pamět' - expozice - ukládání: Muzealizace dějin v česko-německo-slovenském kontextu (Praha: Masarykův ústav AV ČR, 2017). 